This is an Accepted Manuscript of an article published by Taylor \& Francis in Anatolia - An International Journal of Tourism and Hospitality Research on 16 June 2015, available online: https://www.tandfonline.com/doi/full/10.1080/13032917.2015.1042751

\title{
A Portrait of Douglas G. Pearce
}

\section{Christian Schott}

School of Management, Victoria Business School, Victoria University of Wellington, PO Box 600, Wellington, New Zealand. E-mail: Christian.Schott@vuw.ac.nz

\section{Introduction}

I am very pleased to be offered the opportunity to write a portrait of Professor Douglas G. Pearce for Anatolia. Although an autobiographic account of Doug's evolution from 'Geographer to Tourism Geographer to Tourism Management scholar' was published in Stephen Smith's 2010 book The Discovery of Tourism, a comprehensive account of a four decade long contribution to our field is arguably not adequately established without insights on the breadth and depth of a pioneering scholar's contributions by his colleagues and peers. In this context I wholeheartedly embrace this opportunity to share the views of several (indeed I hope most) of Doug's colleagues, peers and mentees about his numerous, longstanding and enduring contributions to our field. My own position is best described by stating that I reside in both the colleague and mentee cohorts. I have had the pleasure of being Doug's colleague in the Tourism Management Group at Victoria University of Wellington (VUW), New Zealand, and co-authored of several of Doug's publications. But at the same time I have benefitted greatly from Doug's advice, guidance and overall leadership of the VUW Tourism Management Group and as such regard him as a longstanding mentor.

\section{His life and journey into tourism academia}

I will begin Doug's portrait with some background information about his life and journey into, as well as through tourism academia. Douglas G. Pearce was born in 1949 and grew up in the rural South Canterbury town of Temuka, New Zealand, known for sheep farming, dairy farming and its own distinctive style of pottery. He went to the University of Canterbury in Christchurch, New Zealand, to study for a Bachelor of Arts in Geography. After he completed his BA in 1970 he pursued a M.A. in Geography, also at Canterbury, for which he 
focused his then dominant interest in Historical Geography on the case of tourist development at New Zealand's Aoraki/Mount Cook (1972). His reasons for subsequently taking the unusual step of commencing a $\mathrm{PhD}$ at the Université d'Aix-Marseille II under the supervision of Bernard Barbier is most richly explained in his chapter in The Discovery of Tourism (2010), but can be summarised to be motivated by three diverse reasons: a lack of tourism expertise in New Zealand's academic institutions at that time, a successful French Government scholarship application and a desire to avoid the common path of New Zealanders to pursue a $\mathrm{PhD}$ in the UK or US. The focus in the last sentence is of course on why he chose to go to France, which leaves the bigger question of why he wanted to pursue a $\mathrm{PhD}$ in the first place begging. In a nutshell the reasons were threefold. He had "caught the research bug" (Pearce, 2010:141) during his Master thesis, which coupled with a passion for the outdoors and a memorable role as the Minister of Tourism for a high school speech competition inspired Doug to pursue a $\mathrm{PhD}$ with a strong tourism focus.

His doctoral journey in Southern France commenced with a number of hurdles which shortly after arrival led him to reflect on the merit of his unconventional decision to come to France for his doctoral studies. For the first two weeks the staff were on strike, the library was closed, and his language skills were pushed to the limits by the French bureaucracy (Pearce, 2010); welcome to continental Europe! During these early days of his PhD with Bernard Barbier he also learned to appreciate the considerable differences in the New Zealand and French schools of thought.

Coming out of Canterbury in the late 1960s/early 1970s, I was steeped in a very systematic approach to geography, I had been exposed to the rapidly evolving urban geography taught by Ron Johnston and had experienced (though not wholly embraced) the quantitative revolution sweeping through Anglo-American geography (Pearce, 2010:142).

At the time of his $\mathrm{PhD}$, the French academic system was dominated by traditional Regional Geography, which resulted in several miscommunications about key concepts. However, these predominantly early challenges were soon negotiated and Doug cherished the opportunity to conduct detailed destination development research in some of the most beautiful parts of France; although he concludes in his chapter that the $\mathrm{PhD}$ experience in France was "at times, difficult and character-building" (Pearce, 2010). After three years in Aix-en-Provence, he submitted and successfully defended his thesis on the systematic 
analysis of the development of nine French resorts and regions (L'aménagement touristique en France: essai d'une approche systématique à partir d'exemples régionaux et locaux).

This extensive doctoral work lay the foundation for his seminal 1981 book Tourist Development: Topics in Applied Geography, as well as his 1978 paper in Annals of Tourism Research (1978b) entitled 'Form and Function in French Resorts'.

Around the same time as his $\mathrm{PhD}$ completion (1975), a lecturing position in Geography had become available at his alma mater back in New Zealand, the University of Canterbury. Keen to return to New Zealand he successfully applied and started as a Lecturer in Geography in 1976. Embracing the newly emerging field of Tourism Geography as a scholarly pursuit, Doug was well placed in New Zealand because the country was experiencing a steady increase in international tourist numbers which gave rise to numerous tourism development-related discussions and initiatives in the late 1970s and early 1980s. Doug focused his early research at Canterbury on applying the learnings from his work in France to various New Zealand case studies. In 1981, owing to his strong publication record (which by then totalled a dozen publications in both French and English) he was promoted to Senior Lecturer. As his reputation and expertise in the field of tourism development grew in the early 1980s, opportunities as a tourism consultant also emerged; these would take him to numerous exotic destinations over the coming two decades. This parallel career as Tourism Development Consultant and Strategic Planner started in 1982 with a project in the small Central American country of Belize (Pearce, 1984), followed by work in Split (then part of Yugoslavia) in 1989 (Pearce, 1991), Sarawak (Malaysia) in 1992-1993, Sabah (Malaysia) in 1995 (Pearce, 1995b), and Samoa in 2000-2001 (Pearce, 2000; 2009a).

Another consequence of completing his $\mathrm{PhD}$ in France is that Doug had developed into a strong advocate for comparative analyses, and the French experience had equipped him with a keen interest and acute awareness of the role of contextual factors in tourism. This passion for learning from other places, cultures, and approaches led him to visiting positions at the University of Hawai' i (USA) in 1989, Universitat Autònoma de Barcelona (Spain) in 1995 and Université de Paris IV (Paris-Sorbonne, France) 1995-1996, along with short research visits to various institutions in Ireland, Belgium and Scandinavia. In the mid-nineties Doug achieved his next promotion to Associate Professor in Geography at the University of Canterbury. It was around this time that he felt increasingly concerned about the prospect of obtaining a Chair at his long-standing institution, University of Canterbury, because of the 
tensions between his position in a Geography Department and his strong interest in tourism. His sentiments at the time are insightfully documented in his 2010 book chapter. He essentially felt that there was both a lack of recognition of tourism research within the Geography Department, as well as a lack of tourism-focused colleagues for external research funding. These stark realisations motivated him in 2000 to successfully apply for the position of Chair in Tourism Management at Victoria University of Wellington (also in New Zealand). In my humble opinion, this move which appears to have been initially motivated more by push than by pull factors, has been to the tremendous benefit of the Tourism Management Programme at VUW, which at the time had only recently been established.

Once Doug had moved to VUW in New Zealand's capital city, Wellington, his energy was solidly focused on activities at his new institution. The biggest demand on his time was the large Foundation for Research in Science and Technology Grant he was awarded by the New Zealand Government in 2001. It funded a multi-researcher project entitled 'Innovation in New Zealand Tourism through Improved Distribution Channels', which sought to develop a systematic understanding of the diverse distribution channels for New Zealand tourism and examine ways of increasing their effectiveness with regard to particular markets, regions and forms of tourism. Doug remained at VUW in the role of Chair of Tourism Management over the ensuing 15 years.

\section{Contributions to Tourism - Geography and Management}

Leaving behind Doug's journey into tourism academia and his milestones as a tourism academic, I will now concentrate on his numerous and extensive contributions to tourism as a field. My first comment is motivated by a personal perspective and seeks to illuminate a lesser-known area of Doug's role as a tourism academic, his contribution to tourism education. I am not specifically referring to his 1981 publication in Annals of Tourism Research, which examines the course content and structure of a Geography of Tourism course and in turn highlights his concern for a meaningful and carefully constructed tourism curriculum, but instead I wish to discuss the applied dimension of this concern; his review of, and long-term development strategy for the Tourism Management Programme at VUW after arriving in 2000. As is common in New Zealand, Professor Pearce is known to virtually everyone, whether undergraduate or postgraduate student, academic colleague, private sector, or public sector partner, simply as Doug. Indeed this relaxed social etiquette was very much part of his approach to his role as Professor of Tourism Management and Head of Group over 
the last 15 years at VUW. Doug's door was always open to all who sought his guidance or critical yet constructive feedback. This has undoubtedly had an impact on his own work.

Hopefully both in a positive sense, in that it gave him deeper involvement with a broad range of topics and methodologies, but will clearly also have resulted in significant opportunity costs, which can likely be equated to several 'extra publications' (as a widely understood currency in today's academy). I personally made repeated use of his supportive attitude towards others who share an interest in tourism, which for his junior colleagues and many $\mathrm{PhD}$ students took on the form of a mentoring relationship spanning anything from three years to more than a decade. From my perspective as a VUW colleague of 12 years this is a tremendously important side of Doug's contribution to our field. His strong passion to both develop the field of tourism (as outlined in detail later) and to assist tourism colleagues and students in refining key academic skills naturally found extension in developing a distinctive, cohesive and highly regarded Tourism Management Programme at VUW. Doug applied the 'systematic approach', which underlies so much of his widely-cited research over the last 40 years, to his vision of a high quality, well-integrated, locally- as well as internationallyrecognised Tourism Management Programme and Tourism Management faculty. Through careful consultative crafting and coordination of the curriculum the undergraduate and postgraduate degrees were revised over several years. These revised degrees (Bachelor of Tourism Management, Bachelor of Tourism Management (Honours) and Master of Tourism Management) as well as the structure and design of the Tourism Management Programme as a whole have been commended by several non-tourism accreditation bodies, as well as receiving UNWTO.TedQual Certification and continual renewal since 2006; in 2013 VUW's Tourism $\mathrm{PhD}$ was included in the application for the first time and also awarded UNWTO.TedQual Certification.

However, arguably the greatest testament to the success of Doug's systematic development and cyclical review of the BTM, BTM (Hons) and MTM degrees is the frequent reference in various parts of the university to the Tourism Management Programme as an excellent example to follow. Further testimony is the VUW Tourism Management graduate community which was formally organised into a successful Alumni Association as part of the development of the Programme and its identity in 2003. There are many more contributions to tourism education and institutional leadership to mention here, however, the significant mark that Doug has made on the tourism literature will require a great deal of this article's 
word count. Thus, I will now turn my attention to the more widely known contributions of Doug's four decade spanning career by reviewing his key publications and evolving areas of interest and research.

Presenting Professor Douglas G. Pearce as an internationally-recognised scholar, it is sufficient as a measure of his esteem to state that he is featured in the top echelon of most analyses of tourism scholars. However, as expressed in his 1992 article in Annals of Tourism Research (1992b) he cautions that these ranking exercises are problematic, a view I share, and as such I will not develop an overview of Doug's 'bibliographic standing'. Instead, a broader statement about Doug's mark on tourism's body of knowledge is that his contributions have not only been deep, but also extensive. To most members of the global tourism community, Doug is best known as one of the two 'prolific Pearces'. He is the Geographer D.G. Pearce who often requires distinction in citations from the Psychologist P.L. Pearce. As comprehensively documented in Doug's 2010 chapter, he is undoubtedly one of the pioneers of tourism and shares his background as a Geographer with several other tourism pioneers, such as Dick Butler and Geoffrey Wall, amongst others. He is widely known for his seminal work on Tourist Development in the book by the same name (1981) which has received 1378 citations at the time of writing, and his related work on Tourist Organisations (1992a), which he explains to be a product of his earlier work on the obstacles and failures of effective tourism development in Europe (Pearce, 2010).

A further book with significant impact and the corollary effect of solidifying Doug's position as a pioneer of tourism is his book Tourism Today: a Geographical Perspective (1988a); due to strong international demand this book was also published in French and Italian and the second edition (1995a) was translated into both Japanese and Portuguese. More books have followed, which have all found an important place in library collections and bookshelves around the world. Several of these are edited books which were developed with long standing collaborator and friend Dick Butler (Pearce and Butler, 1993; 1999; 2010). These edited volumes compile contributions from meetings of the International Academy for the Study of Tourism, of which Doug is a founding Fellow and a former Vice President. However, Doug's most recent book, a monograph under the title Frameworks for Tourism Research (2012), is in many ways a culmination of his work and learnings as both a Tourism Geographer and a Tourism Management scholar with a passion for systematic analysis and models. Its enduring contribution to tourism scholarship is yet to be established due to its 
recent publication date. But as the first book dedicated to tourism frameworks it fills a pivotal gap in researchers' and library bookshelves because the merit of frameworks (be it conceptual, analytical or otherwise) in both tourism research and practice is undeniable.

Although a common association with Doug's work points to his seminal books, he has and continues to have an equally important influence on the field with key journal publications in Annals of Tourism Research, Tourism Management, Journal of Travel Research, amongst many others. Notably, his 1979 article in Annals entitled 'Towards a Geography of Tourism' was an important and much-needed contribution at a time when many Geographers, including himself, were contemplating what the study of tourism could offer Geographers and vice versa. The article is still widely cited by scholars today owing to its considered but firm positioning of tourism on the 'map' of geographical research. Not only does this article remind us that geographical work on tourism dates back to the 1930s (Pearce, 1979), but more importantly it lays out six major areas that are particularly suited to Geographers: spatial aspects of supply, spatial aspects of demand, the Geography of resorts, patterns of movements and flows, the impact of tourism, and models of tourist space. These areas have all evolved into significant tourism research themes over the subsequent decades, and Doug has himself made tremendous contributions to advancing knowledge in the context of several themes. It is also in this seminal paper that he not only lays bare, but also responds to, a very important dynamic in the study of tourism: "it is no exaggeration to say that over threequarters of the significant publications in this field (of international tourism) are in German, French, Italian, Russian and East European languages" (Matley, 1976 in Pearce, 1979:247). Along with his systematic approach, a term already frequently used in these early publications, his desire to incorporate the wealth of tourism knowledge residing in other languages into the English speaking body of tourism knowledge has been an important characteristic of his work over the last four decades. A case in point is this 1979 publication, in which he cites 36 non-English language publications, of which most are French; which of course presented no obstacle to him as he wrote his $\mathrm{PhD}$ thesis at the Université d'AixMarseille II. But also pivotal German and Spanish work was consulted in this paper, which not only allowed valuable knowledge not easily accessible to many in the English-speaking tourism community to be introduced, but it also resulted in Doug being invited to serve on the editorial boards of two Spanish language and one French language journal. These roles were alongside extensive service on the editorial boards of key English language tourism journals 
including Annals of Tourism Research, Tourism Management, Tourism Geographies, Tourism Analysis and Tourism Economics.

Following the initial body of publications (Pearce, 1978a; 1978b; 1980a; 1981a), which was largely driven by a deep interest in tourism development, his research adopted a strong New Zealand framing in the 1980s; a time when New Zealand tourism was rapidly developing , yet poorly understood in other parts of the world. Additionally, Doug was keen to relate his overseas observations and research methods to his home country. This focus on New Zealand tourism resulted in numerous publications (Pearce, 1980b; 1981c; 1987a; Pearce \& Booth, 1987; Pearce \& Elliott 1983; Thomson \& Pearce, 1980), some of which were with postgraduate students. Around the same time, he developed a similarly strong research platform on spatial analysis, a research area that he had identified in his 1979 Annals article, 'Towards a Geography of Tourism'. His spatial analyses focused on various parts of the world (Pearce, 1987b; 1988b; Pearce \& Grimmeau, 1985), but New Zealand was unsurprisingly also a setting where Doug applied this research lens (Forer \& Pearce, 1984; Pearce \& Mings, 1984). While the core of Doug's initial passion for Geography-informed research endured, although in a semi dormant state at times, the 1990s saw him guide numerous postgraduate students through analyses of specific forms of tourism, spanning heritage tourism (Balcar \& Pearce, 1996), eco-tourism (Bottrill \& Pearce, 1996), wildlife viewing tourism (Pearce \& Wilson, 1995), and events tourism (Nicholson \& Pearce, 2000; 2001). During the same decade Doug developed a research interest in European tourism, which evolved as a result of his visiting positions at various European universities in the mid1990s. This interest revolved around the structure and dynamics of tourism in selected European countries (Pearce, 1996a; 1997a; Pearce \& Priestley, 1998) as well as the tourism supporting organisations (Pearce, 1996b; 1996c; 1996d). During this very productive time examining tourism in Europe, Paris in particular caught his attention, and served as an interesting context for a variety of perspectives (Pearce, 1997b; 1998a; 1998b).

After his relocation to Wellington his research activity and related outputs were for several years dominated by the New Zealand Government-funded project on Tourism Distribution Channels (briefly mentioned earlier). The project, which is widely known for its systematic and comprehensive analysis of (a) distribution channel structures and strategies for various markets, regions and tourism products (Pearce, 2007a; Pearce \& Sahli, 2007; Pearce \& Tan, 2004; 2006; Pearce, Tan \& Schott, 2004; 2007), (b) the performance and cost effectiveness of 
different channels (Pearce \& Taniguchi, 2008), (c) demand perspectives (Pearce, Reid \& Schott, 2009; Pearce \& Schott, 2005; 2011) and finally (d) distribution frameworks and models (Pearce, 2008a; 2008b), continued beyond the common three year period and ultimately concluded after five years. By this point the project, which included six VUW Tourism staff members, a research fellow and several Masters students, had received in excess of US\$1 million in research funding and contributed both deep and expansive multistakeholder insights into the complex topic of Tourism Distribution, not only for the benefits of academic, but importantly also private and public sector audiences (Pearce, 2007b).

In his most recent research, which broadly represents the period from the end of the Tourism Distribution Project in 2007 until now, he shows no sign of slowing down and indeed has reinvigorated his original $\mathrm{PhD}$ passion for tourism development. His contemporary interest in destinations has penetrated beyond their development to their management from a multistakeholder perspective (Pearce, 2014; 2015; Pearce \& Schänzel, 2013; 2015), thus combining his background as a Tourism Geographer with his more recent role in Tourism Management.

\section{Conclusion}

Whenever I now (March 2015) walk past Doug's office, his door is unfortunately no longer open to consult and learn from his tremendous journey as a tourism pioneer. He took the step into a highly deserved retirement at the end of January 2015 and I am delighted to say that Doug has just been elevated to the position of Professor Emeritus at VUW. This title pays tribute to the high academic standing he enjoys not just in the field of tourism, but also as a scholar and Professor of Tourism at Victoria University of Wellington. What shape his retirement will take remains to be seen but is likely to involve travel and a desire to learn, which is what initially started his career as a Tourism Geographer in 1973. His colleagues struggle to imagine that such a prolific scholar will simply stop researching and writing; all we know about his current and future plans is that they include a return to the classroom and a visit to Chile. As the first step in his retirement he is sharing the rows of the lecture theatre with undergraduate students in a third year Spanish course to further develop his already fairly proficient Spanish language skills. The many students and colleagues for whom he has been tremendously influential wish him all the best for the next step in his life and hope to cross his path again, be it in Spain, France, South America, Malaysia, Samoa,.....or New Zealand. 


\section{References}

Balcar, M. J., \& Pearce, D. G. (1996). Heritage tourism on the west coast of New Zealand. Tourism Management, 17(3), 203-212.

Bottrill, C. G., \& Pearce, D. G. (1995). Ecotourism: Towards a key elements approach to operationalising the concept. Journal of Sustainable Tourism, 3(1), 45-54.

Forer, P. C., \& Pearce, D. G. (1984). Spatial patterns of package tourism in New Zealand. New Zealand Geographer, 40(1), 34-43.

Nicholson, R., \& Pearce, D. G. (2000). Who goes to events: A comparative analysis of the profile characteristics of visitors to four South Island events in New Zealand. Journal of Vacation Marketing, 6(3), 236-253.

Nicholson, R. E. \& Pearce, D. G. (2001). Why do people attend events: a comparative analysis of visitor motivations at four South Island events. Journal of Travel Research, 39, 449-460.

Pearce, D. G. (1975). L'Aménagement touristique en France: Essai d'une approche systématique à partir d'exemples régionaux et locaux. (Doctoral dissertation).

Pearce, D. G. (1978a). Tourist development: two processes. Travel Research Journal, 1, 4351.

Pearce, D. G. (1978b). Form and function in French resorts. Annals of Tourism Research, $5(1), 142-156$.

Pearce, D. G. (1979). Towards a geography of tourism. Annals of Tourism Research, 6(3), 245272.

Pearce, D. G. (1980a). Tourism and regional development a genetic approach. Annals of Tourism Research, 7(1), 69-82. 
Pearce, D. G. (1980b). Tourist development at Mount Cook since 1884. New Zealand Geographer, 36(2), 81-84.

Pearce, D. G. (1981a). Tourist development. Longman Group Limited.

Pearce, D. G. (1981b). Course content and structure in the geography of tourism the Canterbury example. Annals of Tourism Research, 8(1), 106-115.

Pearce, D. G. (1981c). L'espace touristique de la grande ville [Éléments de synthèse et application à Christchurch (Nouvelle Zélande)]. Espace géographique, 10(3), 207-213.

Pearce, D. G. (1984). Planning for tourism in Belize. Geographical Review, 74(3), 291-303.

Pearce, D. G. (1987a). Motel location and choice in Christchurch. New Zealand Geographer, 43(1), 10-17.

Pearce, D. G. (1987b). Spatial patterns of package tourism in Europe. Annals of tourism research, 14(2), 183-201.

Pearce, D. G. (1988a). Tourism today: a geographical analysis. Harlow: Longman Scientific \& Technical.

Pearce, D. G. (1988b). Tourism and regional development in the European Community. Tourism Management, 9(1), 13-22.

Pearce, D. G. (1991). Challenge and change in East European tourism: a Yugoslav example, in Sinclair, M.T. and Stabler, M. (eds), The Tourism Industry: an international analysis (Oxford, CAB International), pp. 223-40.

Pearce, D. G. (1992a). Tourist Organizations. Harlow: Longman Scientific \& Technical.

Pearce, D. G. (1992b). A response from the Periphery on Authorship Analysis. Annals of Tourism Research, 19(2), 347-349. 
Pearce, D. G. (1993). Domestic tourist travel patterns in New Zealand. GeoJournal, 29(3), 225-232.

Pearce, D. G. (1995a). Tourism today: a geographical analysis (No. Ed. 2). Harlow:

Longman Scientific \& Technical.

Pearce, D. G. (1995b). Planning for tourism in the nineties: an integrated, dynamic, multi-scale approach, in R. W. Butler and Pearce D. G. (eds), Change in Tourism: people, places, processes (London, Routledge), pp. 229-244.

Pearce, D. G. (1996a). Domestic tourist travel in Sweden: A regional analysis. Geografiska Annaler. Series B. Human Geography, 78(2), 71-84.

Pearce, D. G. (1996b). Tourist organisations in Catalonia: Regional and local structures and issues. Progress in Tourism and Hospitality Research, 2(3-4), 307-320.

Pearce, D. G. (1996c). Tourist organizations in Sweden. Tourism Management, 17(6), 413424.

Pearce, D. G. (1996d). Federalism and the organization of tourism in Belgium. European Urban and Regional Studies, 3(3), 189-204.

Pearce, D. (1997a). Tourism and the autonomous communities in Spain. Annals of Tourism Research, 24(1), 156-177.

Pearce, D. G. (1997b). Analyzing the demand for urban tourism: issues and examples from Paris. Tourism Analysis, 1, 5-18.

Pearce, D. G. (1998a). Tourist districts in Paris: structure and functions. Tourism management, 19(1), 49-65.

Pearce, D. G. (1998b). Tourism development in Paris: Public intervention. Annals of Tourism Research, 25(2), 457-476. 
Pearce, D. G. (2000). Tourism plan reviews: methodological considerations and issues from Samoa. Tourism Management, 21(2), 191-203.

Pearce, D. G. (2007). Supplier selection in the New Zealand inbound tourism industry. Journal of Travel \& Tourism Marketing, 23(1), 57-69.

Pearce, D. G. (2007). Paths to the market: Developing an effective tourism distribution strategy. Victoria Management School, Victoria University of Wellington.

Pearce, D. G. (2008a). Beyond tiers: A network approach to tourism distribution. Tourism Analysis, 13(5-6), 517-530.

Pearce, D. G. (2008b). A needs-functions model of tourism distribution. Annals of Tourism Research, 35(1), 148-168.

Pearce, D. G. (2009a). Tourism planning in small tropical islands: methodological considerations and development issues in Samoa, in R. Dowling and C. Pforr (eds) Coastal Tourism Development: planning and management issues (Elmsford, NY, Cognizant Communications), pp.135-150.

Pearce, D. G. (2010). From the Geography of Tourism to Tourism Management. In S.L.J. Smith (ed.) The Discovery of Tourism. Bingley: Emerald Group Publishing pp.139-152.

Pearce, D. G. (2012). Frameworks for tourism research. Wallingford: CABI.

Pearce, D. G. (2014). Toward an integrative conceptual framework of destinations. Journal of Travel Research, 53(2), 141-153.

Pearce, D. G. (2015). Destination management in New Zealand: Structures and functions. Journal of Destination Marketing \& Management, 4(1), 1-12.

Pearce, D. G., \& Booth, K. L. (1987). New Zealand's national parks: use and users. New Zealand Geographer, 43(2), 66-72. 
Pearce, D. G., \& Butler, R. W. (Eds.) (1993). Tourism research: critiques and challenges. London: Routledge.

Pearce, D. G., \& Butler, R. (Eds.). (1999). Contemporary issues in tourism development (Vol. 6). London: Routledge.

Pearce, D. G., \& Butler, R. (Eds.). (2010). Tourism research: a 20-20 vision. Oxford: Goodfellow Publishers.

Pearce, D. G., \& Elliott, J. M. (1983). The trip index. Journal of Travel Research, 22(1), 6-9.

Pearce, D. G., \& Grimmeau, J. P. (1985). The spatial structure of tourist accommodation and hotel demand in Spain. Geoforum, 16(1), 37-50.

Pearce, D. G., \& Mings, R. C. (1984). Geography, tourism and recreation in the Antipodes. GeoJournal, 9(1), 91-95.

Pearce, D. G., \& Priestley, G. K. (1998). Tourism in Spain: a spatial analysis and synthesis. Tourism Analysis, 2, 185-206.

Pearce, D. G., Reid, L., \& Schott, C. (2009). Travel arrangements and the distribution behaviour of New Zealand outbound travelers. Journal of Travel \& Tourism Marketing, 26(1), 80-97.

Pearce, D. G., \& Sahli, M. (2007). Surface transport distribution channels in New Zealand: A comparative analysis. Journal of Travel \& Tourism Marketing, 22(2), 73-87.

Pearce, D. G., \& Schänzel, H. A. (2013). Destination management: The tourists' perspective. Journal of Destination Marketing \& Management, 2(3), 137-145.

Pearce, D. G.; \& Schänzel, H.A. (2015). Destinations: Tourists' Perspectives from New Zealand. International Journal of Tourism Research, 17(1), 4-12. 
Pearce, D. G., \& Schott, C. (2005). Tourism distribution channels: The visitors' perspective. Journal of Travel Research, 44(1), 50-63.

Pearce, D. G., \& Schott, C. (2011). Domestic vs outbound booking and channel choice behavior: evidence from New Zealand. International Journal of Culture, Tourism and Hospitality Research, 5(2), 112-127.

Pearce, D. G., \& Tan, R. (2004). Distribution channels for heritage and cultural tourism in New Zealand. Asia Pacific Journal of Tourism Research, 9(3), 225-237.

Pearce, D. G., \& Tan, R. (2006). The distribution mix for tourism attractions in Rotorua, New Zealand. Journal of Travel Research, 44(3), 250-258.

Pearce, D.G., Tan, R. \& Schott, C. (2004). Tourism distribution channels in Wellington, New Zealand. International Journal of Tourism Research, 6(6), 397-410.

Pearce, D. G., Tan, R., \& Schott, C. (2007). Distribution channels in international markets: a comparative analysis of the distribution of New Zealand tourism in Australia, Great Britain and the USA. Current Issues in Tourism, 10(1), 33-60.

Pearce, D. G., \& Taniguchi, M. (2008). Channel performance in multichannel tourism distribution systems. Journal of Travel Research, 46(3), 256-267.

Pearce, D. G., \& Wilson, P. M. (1995). Wildlife-viewing tourists in New Zealand. Journal of Travel Research, 34(2), 19-26.

Thomson, C. M., \& Pearce, D. G. (1980). Market segmentation of New Zealand package tours. Journal of Travel Research, 19(2), 3-6. 